\title{
Efficacy of Beauveria bassiana against the cotton leaf roller, Haritalodes (Syllepte) derogata (Fabricius, 1775) (Lepidoptera: Crambidae) under laboratory conditions.
}

\author{
Dannon H. Fabrice 1,4,", Douro Kpindou O. Kobi4, Toffa Mehinto Joelle ${ }^{3}$, Zantchedji D. M. Désiré1, \\ Zinsou A. Valerien 1 , Dannon A. Elie2,4, Houndété A. Thomas ${ }^{5}$, Elégbédé I. A. Maurille T.1, Olou B. \\ Dénis ${ }^{6}$ \\ 'Laboratoire de Phytotechnie, d'Amélioration et de Protection des Plantes (LaPAPP), Faculté d'Agronomie (FA), \\ Université de Parakou, Parakou, Bénin \\ ${ }^{2}$ Ecole Normale Supérieure (ENS), Université Nationale des Sciences, Technologies, Ingénierie et Mathématiques \\ d'Abomey, Natitingou, Bénin \\ ${ }^{3}$ Faculté des Sciences et Techniques (FAST), Université Nationale des Sciences, Technologies, Ingénierie et \\ Mathématiques, Dassa-Zoumè, Bénin \\ ${ }^{4}$ Institut International d'Agriculture Tropicale, 08 BP 0932 Tri Postal, Cotonou, Benin. \\ ${ }^{5}$ Centre de Recherches Agricoles Coton et Fibres (CRA-CF), Institut National de Recherches Agricoles, Bohicon, Bénin \\ 6Programme Analyse de la Politique Agricole, Centre de Recherches Agricoles, Institut National de Recherches \\ Agricoles, (PAPA/CRA-A/INRAB), Agonkanmey, Bénin \\ *Corresponding author : Dannon Houénoudé Fabrice, Contact : (+229) 95274027, e-mail : icedannon@gmail.com \\ Original submitted in on $16^{\text {th }}$ October 2020. Published online at www.m.elewa.org/journals/ on $31^{\text {st }}$ January 2021 \\ https://doi.org/10.35759/JABs.157.10
}

\begin{abstract}
Objective: The leaf-roller caterpillar Haritalodes (=Syllepte) derogata (Fabricius, 1775) (Lepidoptera: Crambidae) induces high yield losses by damaging cotton leaves and reducing the photosynthetic activity of the plant. Laboratory bioassays were carried to evaluate the effect of Beauveria bassiana on the survival of $H$. derogata larvae.

Methodology and results: In the first trial, screening of thirteen $B$. bassiana isolates was performed on third larval instars at $10^{7}$ conidia. $\mathrm{mL}^{-1}$. In the second trial, effects of five concentrations ( $10^{5}$ to $10^{9}$ conidia. $\mathrm{mL}^{-1}$ ) of the three best isolates of the fungus were tested. Conidia suspension was applied on each larva topically. Germination rates of conidia used varied between $90.2 \%$ to $95.7 \%, 24$ hours after incubation. Five isolates were found to be the most promising namely $\mathrm{Bb} 116, \mathrm{Bb} 3, \mathrm{Bb} 11, \mathrm{Bb} 6$ and $\mathrm{Bb} 115$. In the second bioassay, caterpillar mortality increased with fungal concentration. Lethal Concentration (LC50) was estimated to $1.18 \times 10^{15}$ conidia. $\mathrm{mL}^{-1}, 1.75 \times 10^{13}$ conidia. $\mathrm{mL}^{-1}, 1.75 \times 10^{13}$ conidia. $\mathrm{mL}^{-1}, 9$ days after inoculation for $\mathrm{Bb} 3, \mathrm{Bb} 11$ and $\mathrm{Bb} 115$, respectively.

Conclusion and application of results: The use of $B$. bassiana as a biopesticide against $H$. derogata could be a good alternative method to control the pest. It is an environmentally friendly method with less side effects compared to the application of synthetic pesticides on cotton. This method could be tested in future station and field experiments.
\end{abstract}

Keywords: Cotton, Integrated pest management, Haritalodes (=Syllepte) derogata, Beauveria bassiana, Lethal Concentration. 


\section{INTRODUCTION}

Cotton crop is the first cash crop of Benin that contributes up to $80 \%$ to official export earnings and $13 \%$ to GDP (Great Development Product) (Afouda et al., 2013). In 2018-2019 season, the recorded production was 700,000 TM ranking Benin as the largest producer in West Africa (Tonavoh, 2019). This increase in cotton production is related to the expansion of cultivated areas and the use of new cotton varieties but not to an increase in yield (CRACF 2018). Yield is heavily limited by pressure from insect pests. In West Africa, insect pests become a major constraint on increasing cotton production (Brevault et al., 2017). Indeed, cotton is the one of the most damaged crops with more than 1300 species of insect pests, heavily limiting its productivity (UNCTAD, 2008 cited by Douro Kpindou et al., 2013). Among these, phyllophagous and carpophagous caterpillars are the most destructive pests of cotton in Benin. There are two main groups of caterpillar pests according to their feeding preferences (Héma et al., 2009). The first group consisted of defoliators such as the leaf-roller caterpillar Haritalodes (=Syllepte) derogate F. (Crambidae)), the leaf-eating noctuids Anomis flava F. and Spodoptera littoralis (Boisduval). On the other hand the second group includes bollworms or fruit-feeders namely the old world bollworm Helicoverpa armigera (Hubner), the red bollworm Diparopsis watersi Rothschild and the spiny bollworms Earias insulana (Boisduval) and Earias biplaga (Walker) which feed on fruiting organs (squares, flowers, bolls) (Silvie et al., 2013). Expansion of cultivated area led to higher consumption of chemical pesticides in order to overcome insect pests damage (Westerberg, 2017). The side effects of chemical insecticide misuses included the contamination of cotton production area, human hazards (frequent pesticide poisoning, skin and stomach irritation), insect pest resurgence and resistance, environmental pollution (Lawani et al., 2017; Djihinto et al., 2016; Djihinto et al., 2009). Cotton is an income generating for all stakeholders in the value chain and insect resistance mainly of Lepidopteran species became a major issue to be solved for boosting cotton production in Benin. Among these caterpillars of cotton, $\mathrm{H}$. derogata (Fabricius, 1775) (Lepidoptera: Crambidae) inducing up to $20-60 \%$ of cotton yield loss (Silvie, 1993). Thus, this phyllophagous could alter the photosynthetic activity of the plant. In order to economically and ecologically manage cotton insect pests, biological control remains an attractive option. This control option includes the use of natural enemies of target insect pest species. Several studies reported various natural enemies (parasitoids and pathogens) of $H$. derogata (Gahramanova et al., 2020). In this perspective, the entomopathogen Beauveria bassiana (Bals.-Criv.) Vuill., 1912, is a promising candidate. Different isolates were identified infecting a wide range of insects (707 species belong to 15 orders) and mites (13 species) (Zimmerman 2007; Lambert 2010). The use of $B$. bassiana is an environmentally friendly control mean and harmless to human health compared to chemical pesticides (Althouse et al., 1997; Faria and Wraight, 2001). Fungus kills both susceptible adult and immature stages (eggs, larvae) causing the so-called "white muscardine" disease by a simple contact. Pest mortality may occur with the conidia development process and dead host becomes a new source of contamination. Four steps are known for the infection of the fungus namely adhesion, germination and differentiation, penetration, and dissemination within the host and to another host (Dannon et al., 2020). It is not theoretically possible for insects to develop resistance to $B$. bassiana because the fungus simultaneously uses several modes of action such as infection by conidia and toxins (Mascarin and Jaronski, 2016) and as a living organism, it can adapt to various host changes (Sabbahi, 2008). The present study was designed to assess the susceptibility of $H$. derogata to various $B$. bassiana isolates under laboratory conditions. 
Dannon et al., J. Appl. Biosci. 2021 Efficacy of Beauveria bassiana against the cotton leaf roller, Haritalodes (Syllepte) derogata (Fabricius, 1775) (Lepidoptera: Crambidae) under laboratory conditions.

\section{MATERIALS AND METHODS}

Insects: Larvae of $H$. derogata were collected during the period of 12 to 15 October 2017 on untreated cotton plants samples at the experimental site of the agricultural research center, cotton and fiber (CRA-CF), in two regions of central Benin namely Savalou $\left(07^{\circ} 54^{\prime} .032^{\prime \prime} \mathrm{N}\right.$; $001^{\circ} 55^{\prime} .024^{\prime \prime} \mathrm{E} ; \quad 179 \mathrm{~m}$ of altitude) and Savè $\left(08^{\circ} 00^{\prime} .003^{\prime \prime} \mathrm{N} ; 002^{\circ} 25^{\prime} .054^{\prime \prime} \mathrm{E} ; 175 \mathrm{~m}\right.$ of altitude). They were reared at $(26 \pm 1){ }^{\circ} \mathrm{C},(70 \pm 5) \% \mathrm{HR}$ and a photoperiod of $12: 12$ (L: D) $h$ in the laboratory at
International Institute of Tropical Agriculture (IITA), Benin station. They were fed using untreated cotton leaves. The first generation was used in the different bioassays. Only, the third larval instars were tested with $B$. bassiana isolates.

Fungal isolates: Thirteen isolates were used in the first trial and the best three ones were retained for the second experiment. All isolates were obtained from the collection unit of IITA-Benin (Table 1).

Table 1: Information about $B$. bassiana isolates used in different trials.

\begin{tabular}{|c|c|c|c|c|}
\hline Range & $\begin{array}{l}\text { Abbreviation of fungal } \\
\text { isolates }\end{array}$ & Register $\mathrm{N}^{\circ}$ & $\begin{array}{c}\text { Host } \\
\text { (Country of origin. } \\
\text { district) }\end{array}$ & $\begin{array}{c}\text { Auteur } \\
\text { (Year of isolation) }\end{array}$ \\
\hline 1 & $\mathrm{Bb} 2$ & 5644 & $\begin{array}{l}\text { Eldana sacharina } \\
\text { (Benin, Atlantique) }\end{array}$ & -IITA-Benin (1997) \\
\hline 2 & $\mathrm{Bb3}$ & 5645 & $\begin{array}{l}\text { Eldana sacharina } \\
\text { (Benin, Atlantique)) }\end{array}$ & -IITA-Benin (1997) \\
\hline 3 & Bb5 & 5647 & $\begin{array}{l}\text { Acigona sp. } \\
\text { (Nigeria, Ikom) }\end{array}$ & - IITA-Benin (1997)- \\
\hline 4 & $\mathrm{Bb} 6$ & 5648 & $\begin{array}{l}\text { Acigona sp. } \\
\text { (Benin, Alibori) }\end{array}$ & - IITA-Benin (1997)- \\
\hline 5 & $\mathrm{Bb} 11$ & 5653 & $\begin{array}{l}\text { Sesamia calamistis } \\
\text { (Benin, Atlantique)) }\end{array}$ & -IITA-Benin (1997) \\
\hline 6 & Bb115 & 193-841 & $\begin{array}{l}\text { Locusta migratoria } \\
\text { (Madagascar, Toliara) }\end{array}$ & -Madagascar (1993) \\
\hline 7 & $\mathrm{Bb} 69$ & $191-623$ & $\begin{array}{l}\text { Zonocerus variegatus } \\
\text { (Benin, Atlantique) }\end{array}$ & -IITA-Benin (1991) \\
\hline 8 & $\mathrm{Bb} 71$ & $191-592$ & $\begin{array}{l}\text { Zonocerus variegatus } \\
\text { (Benin, Atlantique) }\end{array}$ & -IITA-Benin (1991) \\
\hline 9 & Bb84 & $191-679$ & $\begin{array}{l}\text { Hieroglyphus } \\
\text { (Benin, Alibori) }\end{array}$ & -IITA-Benin (1998) \\
\hline 10 & Bb353 & - & $\begin{array}{l}\text { Callosobruchus sp. } \\
\text { (Benin, Ouémé) }\end{array}$ & -IITA-Benin (2001) \\
\hline 11 & Bb116 & $193-842$ & $\begin{array}{l}\text { Locusta migratoria } \\
\text { (Madagascar, vatolalaka) }\end{array}$ & -Madagascar (1993) \\
\hline 12 & $\mathrm{Bb} 338$ & 2191 ARSEF & $\begin{array}{l}\text { Pentatomidae Oebalus } \\
\text { (Brazil, Fazenda) }\end{array}$ & $\begin{array}{l}\text { - Cornell University } \\
\text { (USA, 1986) }\end{array}$ \\
\hline 13 & Bb339 & 3086 ARSEF & $\begin{array}{l}\text { Leptoglossus fulvicorni } \\
\text { (USA, Florida) }\end{array}$ & $\begin{array}{l}\text {-Cornell University } \\
\text { (USA, 1990) }\end{array}$ \\
\hline
\end{tabular}


Isolates were mass cultured in petri dishes $(9 \mathrm{~cm}$ diameter) containing Potato Dextrose Agar (PDA) and incubated at $26 \pm 1^{\circ} \mathrm{C}$. When isolates sporulated after fifteen days, conidia of each isolate were harvested with $0.05 \%$ of Tween 80 and filtered. After serial dilution of initial conidial suspension of each isolate, viability of conidia was checked on PDA inoculated with $100 \mu \mathrm{L}$ of the lowest diluted suspension $\left(\sim 10^{4}\right.$ conidia. $\left.\mathrm{mL}^{-1}\right)$. Twenty-four (24) hours later, conidia were counted using a sub-sample of 100 , and viable conidia were estimated (formula 1) and conidia concentration to be used was calculated accordingly (formula 2) (Douro Kpindou et al., 2012).

$$
\% \text { Viable }=\left[\frac{a}{a+b}\right] \times 100
$$

$a=$ number of germinated conidia within 24 hours; $b=$ number of non-germinated conidia.

$$
\mathrm{C}^{\prime}=\frac{\mathrm{Co} \times \mathrm{Vo}}{\mathrm{Vo}+\mathrm{V}^{\prime}}
$$

$C^{\prime}=$ concentration to be used, $\mathrm{Co}=$ concentration of initial conidial suspension;

$V_{0}=$ volume needed and $V^{\prime}=$ volume to be added .

\section{Bioassays}

Screening of $B$. bassiana isolates: Isolates of $B$. bassiana were formulated with Tween $80(0.05 \%)$ at the concentration $10^{7}$ conidia. $\mathrm{mL}^{-1}$. Hundred-twenty larvae of $H$. derogata were used for the bioassay. Third instars larvae were individually placed in rearing boxes $(3.8 \mathrm{~cm}$ $\times 2.9 \mathrm{~cm} \times 4.0 \mathrm{~cm}$ ) with punched tiny holes for ventilation. There were thirteen isolates used and each of these was tested on twenty larvae replicated three times in a completely randomized block. Larvae were inoculated by the method of Bateman et al. (1996) and Peveling et al. (1997). Each larva received topically $1 \mu \mathrm{L}$ of the fungal suspension on the pronotum at a concentration of $10^{7}$ conidia. $\mathrm{mL}^{-1}$. The rates of germination varied from $90.2 \%$ to $95.7 \%, 24$ hours after incubation. Conditions of the laboratory were $26 \pm 1^{\circ} \mathrm{C}$ and $70 \pm 5 \%$ for averages of temperature $(\mathrm{T})$ and relative humidity $(\mathrm{RH})$ respectively.

\section{RESULTS}

Screening test of isolates: Results from the screening of $B$. bassiana isolates revealed the pathogenicity of $B$.
Mortality of larvae was checked daily over 15 days. Cadavers were dried for 48-72 hours, and transferred in petri dishes $(9 \mathrm{~cm}$ diameter) containing humidified Whatman filter paper, sealed with parafilm and incubated at $26^{\circ} \mathrm{C}$ to check sporulation. The number of pupae formed, dead and sporulated larvae and adults emerged were also recorded.

Assessing of effect of different concentrations of $B$. bassiana on the survival of $H$. derogata larvae: Three isolates $(\mathrm{Bb} 3, \mathrm{Bb} 11$ and $\mathrm{Bb} 115)$ of $B$. bassiana were used in the current bioassay. Treatments consisted of a control (Tween 80 à $0.05 \%$ without fungus) and five different concentrations $\left(10^{5}, 10^{6}, 10^{7}, 10^{8}, 10^{9}\right.$ conidia. $\mathrm{mL}^{-1}$ corresponding to $10^{2}, 10^{3}, 10^{4}, 10^{5}, 10^{6}$ conidia per insect) tested using $3^{\text {rd }}$ larval instars of $H$. derogata.

Data analysis: Mortality rate was estimated based on the OECD approach (OECD, 2010).

$$
\mathrm{MR}=\frac{\mathrm{Nd}}{\mathrm{Nu}}
$$

$\mathrm{MR}=$ mortality rate, $\mathrm{Nd}=$ number of dead larvae, $\mathrm{Nu}=$ number of larvae used (normally 20). Sporulation rate was assessed basing on the number of larvae dead in each treatment. Likewise, the emergence rate was estimated based on the number of pupae formed by treatment. Percentages were converted in "Arcsin (square (p)) transformation" before statistical analysis. Transformed data related to mortality, sporulation and emergence were subjected to Fisher's analysis of variance (ANOVA) (Steel et al., 1997), using the general linear model (GLM) procedure of SAS (Version 9.2). The post hoc test of Tukey (HSD) at 95\% probability was used to separate the means after ANOVA indicated at $5 \%$. The lethal concentrations and lethal times were estimated using the model of Cox regression (SPSS, 1989- 2007) as described by Douro Kpindou et al. (2012).

bassiana isolates on third larval instars of $H$. derogata (Fig. 1). 


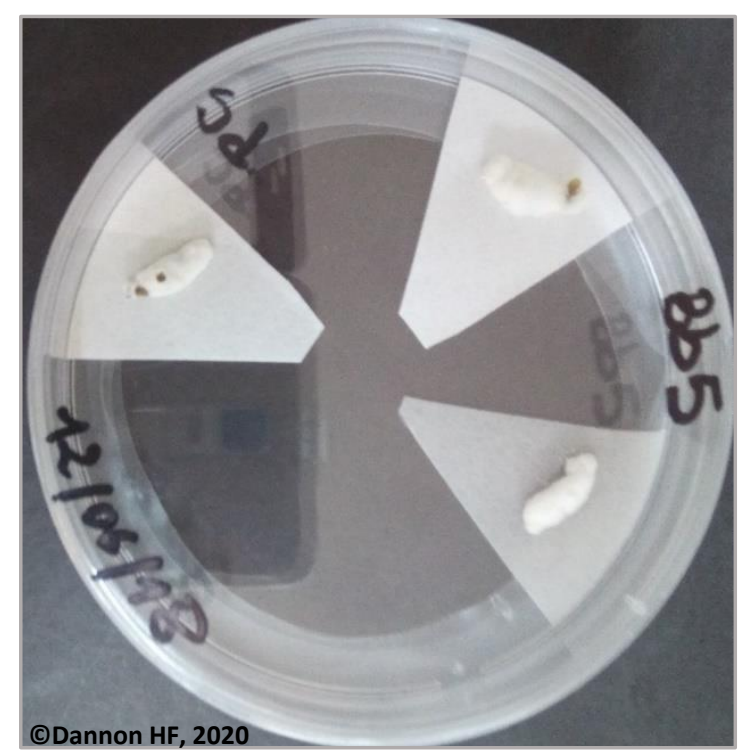

Fig. 1 Sporulation of $B$. bassiana on third larval instars of Haritalodes (=Syllepte) derogata.

Significant differences were observed between the tested isolates when considered larval mortality $(F=8.1464, P<0.0001)$ and sporulation rate of dead larvae $(F=3.9333, P<0.01)$ (Fig. 2 and Fig. 3). Indeed, after the fifteenth days of inoculating larvae, the cumulative mortality varied from $16.67 \pm 4.40 \%$ (isolate $\mathrm{Bb} 69)$ to $73.33 \pm 1.66 \%(\mathrm{Bb} 2)$ compared to the control $(3.33 \pm 1.66 \%)$. The highest recorded mortality rates were $73.33 \pm 1.66 \%, 46.66 \pm 4.40 \%, 43.33 \pm 7.26 \%$, $41.66 \pm 3.33 \%, 41.66 \pm 8.81 \%, 33.33 \pm 3.33 \%, 33.33 \pm$ $6.66 \%$ and $31.66 \pm 4.44 \%$ for $\mathrm{Bb} 2, \mathrm{Bb} 5, \mathrm{Bb} 116, \mathrm{Bb} 3$,
$\mathrm{Bb} 11, \mathrm{Bb} 6, \mathrm{Bb} 71$ and $\mathrm{Bb} 115$, respectively. On the other hand, the sporulation rate of dead larvae was from 3.70 $\pm 3.70 \%(\mathrm{Bb} 5)$ to $43.61 \pm 3.95 \%$ (Bb116) after incubation. The highest recorded sporulation rates were $43.60 \pm 3.95 \%, 26.98 \pm 6.34 \%, 25.00 \pm 14.43 \%, 21.54$ $\pm 17.20 \%$ and $20.55 \pm 2.42 \%$ for $\mathrm{Bb} 116, \mathrm{Bb} 3, \mathrm{Bb} 6, \mathrm{Bb} 11$ and $\mathrm{Bb} 115$ respectively. However, the sporulation rate was lower on larvae dead following the activity of $\mathrm{Bb} 2$ (9.04 $\pm 2.14 \%), \mathrm{Bb} 5(3.70 \pm 3.70 \%)$ and $\mathrm{Bb} 71$ (8.33 \pm $8.33 \%)$. Moreover, no sporulation was observed for the isolates $\mathrm{Bb} 338, \mathrm{Bb} 353, \mathrm{Bb} 69$, and $\mathrm{Bb} 84$.

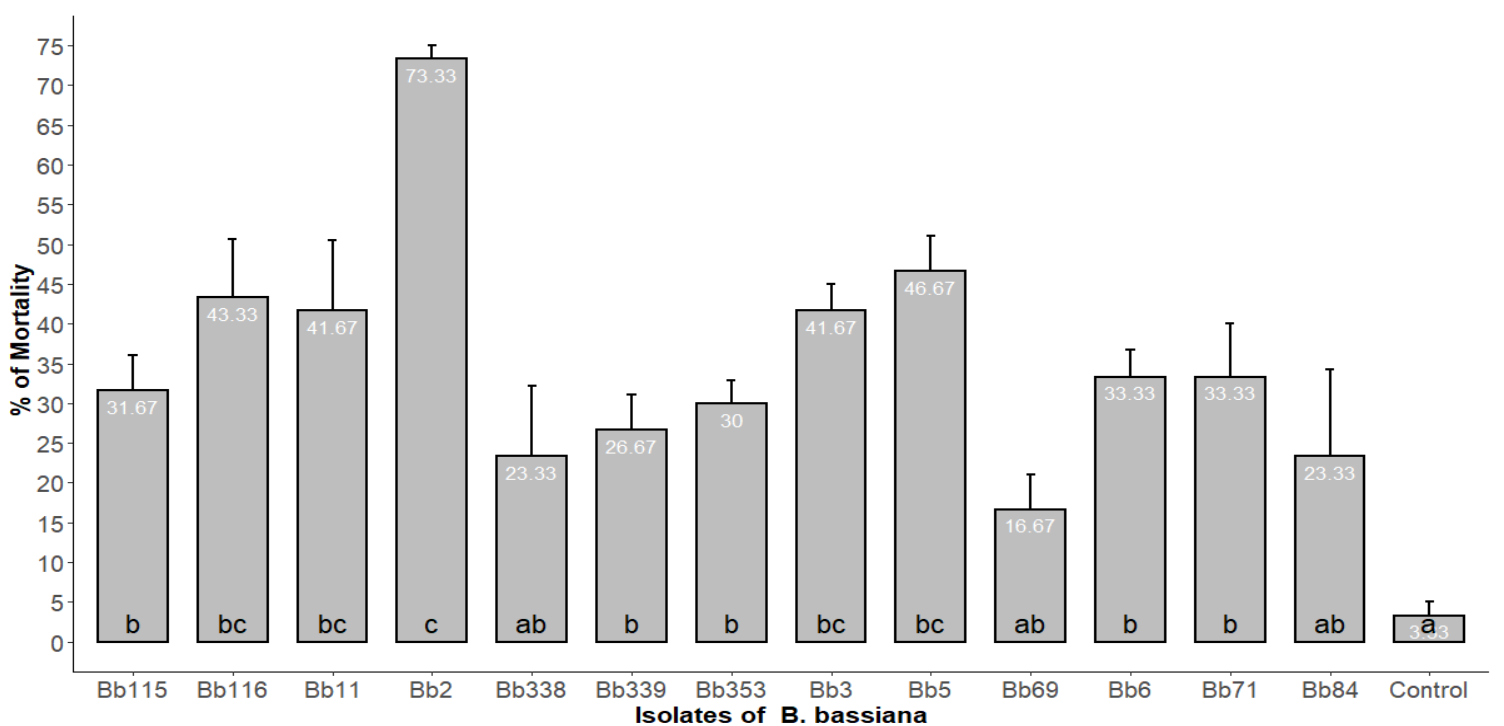

Fig. 2 Mean mortality rates induced by $13 \mathrm{~B}$. bassiana isolates at $10^{7}$ conidia. $\mathrm{mL}^{-1}$ on third larval instars (L3) of $H$. derogate 


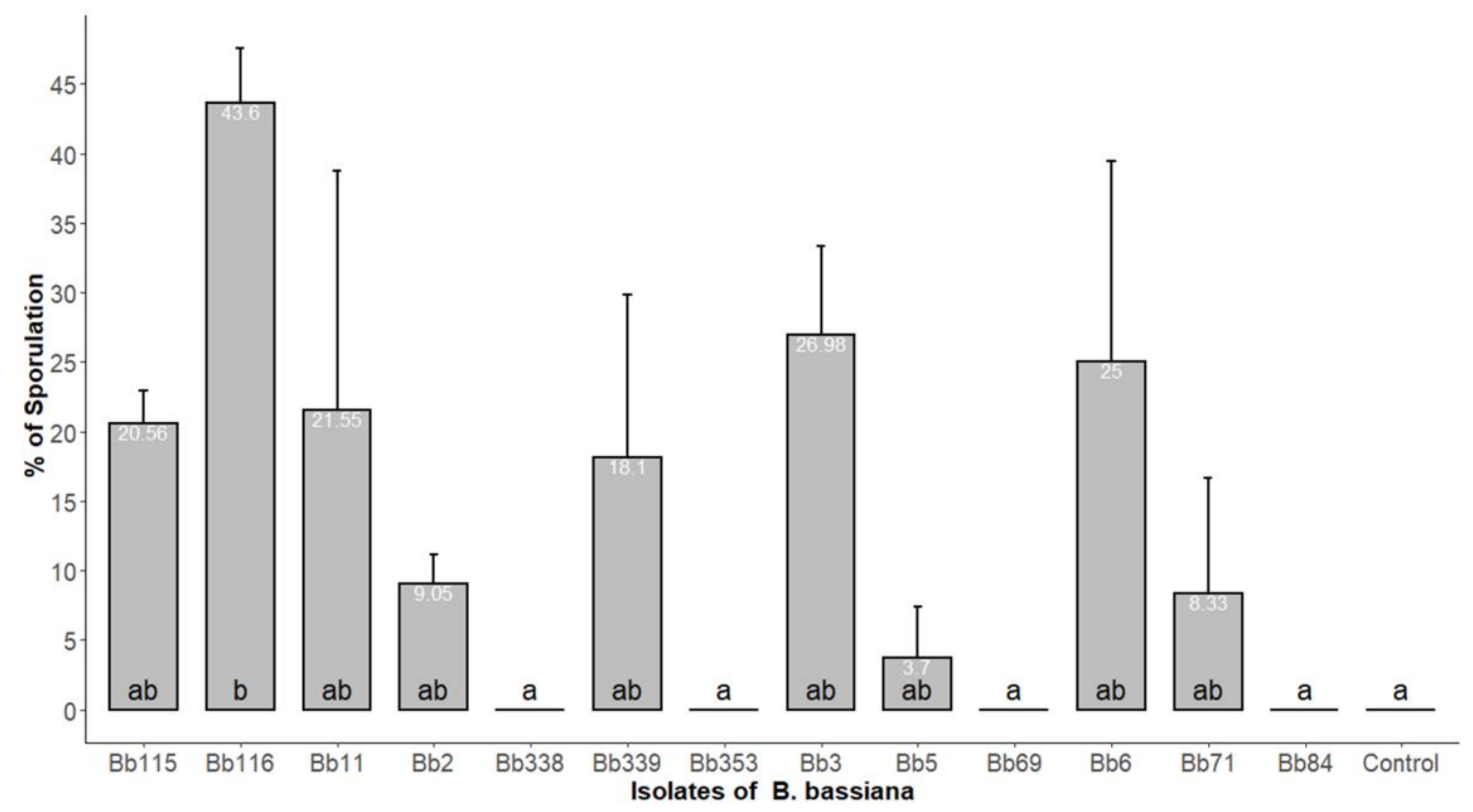

Fig. 3 Mean sporulation rates of $13 B$. bassiana isolates at $10^{7}$ conidia. $\mathrm{mL}^{-1}$ on third larval instars (L3) of $H$. derogata.

Assessing of effect of different $B$. bassiana concentrations on the survival of $H$. derogata larvae Effect of $B$. bassiana on third larvae stage and adults emergence: The larval mortality rates increased with fungal concentrations (Table 2). The mortality induced varied from $31.66 \pm 4.40 \%$ to $63.33 \pm 4.40 \%, 33.33 \pm$ $3.33 \%$ to $76.66 \pm 1.66 \%$ and $31.66 \pm 1.66 \%$ to 58.33 $\pm 4.41 \%$ for the isolates $\mathrm{Bb} 3, \mathrm{Bb} 11$ and $\mathrm{Bb} 115$, respectively. For the isolate $\mathrm{Bb} 3$, there was no difference for larval mortality obtained at the first and the second concentrations, and at the third and fourth concentrations. The highest mortality rate was recorded
$(63.33 \pm 4.40 \%)$ at the concentration of $10^{9}$ conidia. $\mathrm{mL}^{-}$ ${ }^{1}$. In isolate $\mathrm{Bb} 11$, there was a significant difference between the mortality rates $(60.00 \pm 5.77 \%$ and $76.66 \pm$ $1.66 \%$ ) at $10^{8}$ and $10^{9}$ conidia. $\mathrm{mL}^{-1}$, respectively. In the isolate $\mathrm{Bb} 115$ any significant differences were not observed between the first 4 concentrations and the highest mortality was obtained $(58.33 \pm 4.41 \%)$ at the concentration of $10^{9}$ conidia. $\mathrm{mL}^{-1}$. When comparing isolates within each concentration, there was a significant difference within isolates at $10^{9}$ conidia. $\mathrm{mL}^{-1}$. The isolate $\mathrm{Bb} 11$ induced the highest mortality rate (76.66 $\pm 1.66 \%$ ) compared to $\mathrm{Bb} 3$ and $\mathrm{Bb} 115$ at $10^{9}$ conidia. $\mathrm{mL}^{-1}$. 
Dannon et al., J. Appl. Biosci. 2021 Efficacy of Beauveria bassiana against the cotton leaf roller, Haritalodes (Syllepte) derogata (Fabricius, 1775) (Lepidoptera: Crambidae) under laboratory conditions.

Table 2: Effects of $B$. bassiana on third larval instars of Haritalodes derogata

\begin{tabular}{|c|c|c|c|c|}
\hline \multirow{2}{*}{$\begin{array}{l}\mathrm{Bb} \\
\text { Concentration } \\
\text { (Conidia/ml) }\end{array}$} & \multicolumn{3}{|c|}{ Mortality rate of larvae (\%) } & \multirow[b]{2}{*}{ ANOVA } \\
\hline & Bb3 & Bb11 & Bb115 & \\
\hline $10^{5}$ & $31.66 \pm 4.40 \mathrm{bA}$ & $33.33 \pm 3.33 \mathrm{bA}$ & $31.66 \pm 1.66 \mathrm{bA}$ & $\begin{array}{l}F=0.0904 \\
P=0.9154\end{array}$ \\
\hline $10^{6}$ & $33.33 \pm 3.33 \mathrm{bA}$ & $40.00 \pm 2.88 \mathrm{bA}$ & $35.00 \pm 2.88 \mathrm{bA}$ & $\begin{array}{l}F=1.1331 \\
P=0.4075\end{array}$ \\
\hline $10^{7}$ & $43.33 \pm 9.27 \mathrm{bcA}$ & $45.00 \pm 5.00 \mathrm{bA}$ & $36.66 \pm 1.66 \mathrm{bA}$ & $\begin{array}{l}F=0.5900 \\
P=0.5963\end{array}$ \\
\hline $10^{8}$ & $53.33 \pm 3.33 \mathrm{bcA}$ & $60.00 \pm 5.77 \mathrm{bcA}$ & $41.66 \pm 4.40 \mathrm{bA}$ & $\begin{array}{l}F=6.0523 \\
P=0.06169\end{array}$ \\
\hline $10^{9}$ & $63.33 \pm 4.40 \mathrm{cA}$ & $76.66 \pm 1.66 \mathrm{cB}$ & $58.33 \pm 4.41 \mathrm{cA}$ & $\begin{array}{l}F=14.8527 \\
P=0.01408\end{array}$ \\
\hline Control & $8.33 \pm 1.66 \mathrm{aA}$ & $8.33 \pm 4.40 \mathrm{aA}$ & $8.33 \pm 4.40 \mathrm{aA}$ & $\begin{array}{l}F=0.3001 \\
P=0.7540\end{array}$ \\
\hline ANOVA & $\begin{array}{l}F=15.5130 \\
P=0.0001961\end{array}$ & $\begin{array}{l}F=18.6442 \\
P=8.824 \mathrm{e}-05\end{array}$ & $\begin{array}{l}F=32.2840 \\
P=7.355 \mathrm{e}-06\end{array}$ & \\
\hline
\end{tabular}

${ }^{*}$ There is no significant difference between means followed by the same lowercase letters

shown in the same column (ANOVA followed by Tukey test at $5 \%$ ).

*There is no significant difference between means followed by the same capital letters

shown in the same line (ANOVA followed by Tukey test at $5 \%$ ).

The emergence rate of $H$. derogata adults decreased with the increase in fungal concentrations (Table 3). Adult emergence was significantly affected by concentrations in each isolate $(P<0.05)$. Nevertheless, when comparing isolates for each concentration, no significant differences occurred.

Table 3: Effects of $B$. bassiana on emergence of Haritalodes derogata

\begin{tabular}{|c|c|c|c|c|}
\hline \multirow{2}{*}{$\begin{array}{l}\mathrm{Bb} \\
\text { Concentration } \\
\text { (Conidia/ml) }\end{array}$} & \multicolumn{4}{|c|}{ Emergence rate of moths (\%) } \\
\hline & Bb3 & Bb11 & Bb115 & ANOVA \\
\hline $10^{5}$ & $79.84 \pm 7.56 \mathrm{abA}$ & $75.39 \pm 5.72 \mathrm{abA}$ & $80.58 \pm 4.58 \mathrm{abA}$ & $\begin{array}{l}F=0.3723 \\
P=0.7107\end{array}$ \\
\hline $10^{6}$ & $70.63 \pm 7.57 \mathrm{aA}$ & $88.38 \pm 5.82 \mathrm{bA}$ & $79.80 \pm 4.19 \mathrm{aA}$ & $\begin{array}{l}F=4.8867 \\
P=0.08434\end{array}$ \\
\hline $10^{7}$ & $85.55 \pm 8.67 \mathrm{abA}$ & $61.28 \pm 4.70 \mathrm{abA}$ & $76.06 \pm 5.19 \mathrm{aA}$ & $\begin{array}{l}F=2.3823 \\
P=0.2083\end{array}$ \\
\hline $10^{8}$ & $68.33 \pm 4.40 \mathrm{aA}$ & $55.55 \pm 5.55 \mathrm{abA}$ & $73.97 \pm 2.06 \mathrm{aA}$ & $\begin{array}{l}F=4.7484 \\
P=0.08783\end{array}$ \\
\hline $10^{9}$ & $71.95 \pm 3.21 \mathrm{aA}$ & $33.33 \pm 17.63 \mathrm{aA}$ & $63.21 \pm 3.72 \mathrm{aA}$ & $\begin{array}{l}F=3.0347 \\
P=0.1578\end{array}$ \\
\hline Control & $96.29 \pm 3.70 \mathrm{bA}$ & $92.96 \pm 3.53 \mathrm{bA}$ & $96.29 \pm 3.70 \mathrm{bA}$ & $\begin{array}{l}F=0.2310 \\
P=0.8043\end{array}$ \\
\hline ANOVA & $\mathrm{F}=4.9185 \mathrm{P}=0.01568$ & $\mathrm{~F}=4.899 \mathrm{P}=0.01129$ & $\begin{array}{l}F=6.9204 \\
P=0.004876\end{array}$ & \\
\hline
\end{tabular}

${ }^{*}$ There is no significant difference between means followed by the same lowercase letters shown in the same column (ANOVA followed by Tukey test at $5 \%$ ).

*There is no significant difference between means followed by the same capital letters shown in the same line (ANOVA followed by Tukey test at 5\%). 
Lethal concentration (LC50) of B. bassiana on third larvae stage: Analysis of Cox regression indicated that the different fungal concentrations used were significant and affected larval survival $(P<0.05)$ (Table 4). The model provided a good estimation of the different parameters. Values of $B$ showed the existence of a doseresponse relationship. This relationship was strong for the $B b 11$ isolate giving the highest $B$ value $(B=0.087)$.

Table 4: Estimation of $B$ values and Wald coefficients with Cox regression model for $B$. bassiana and third instars larvae of $H$. derogata

\begin{tabular}{|l|l|l|l|l|l|l|}
\hline $\begin{array}{l}\text { B. bassiana } \\
\text { isolate }\end{array}$ & $\begin{array}{l}\text { H. derogata } \\
\text { stage }\end{array}$ & B & SE & Wald & df & Sig. \\
\hline Bb3 & L3 & 0.069 & 0.019 & 13.755 & 1 & 0.000 \\
\hline Bb11 & L3 & 0.087 & 0.019 & 20.589 & 1 & 0.000 \\
\hline Bb115 & L3 & 0.055 & 0.018 & 8.932 & 1 & 0.003 \\
\hline
\end{tabular}

B: B value of the Cox regression; SE: standard error; Wald: Wald coefficient; df: degree of freedom; Sig: probability.

The LC50 curves for isolates are depicted in figures $\mathbf{( 5 ,}$ 6 and 7). For all isolates, the dose-response effect was significant and depends on the $B$ value. Higher is $B$ value, the narrower are the confidence intervals. It had to $3.52 \times 10^{26}, 5.17 \times 10^{20}$ and $1.18 \times 10^{15}$ conidia. $\mathrm{mL}^{-1}$ of isolate $\mathrm{Bb} 3$, i.e. $3.52 \times 10^{23}, 5.17 \times 10^{17}$ and $1.18 \times 10^{12}$ conidia by insects to kill $50 \%$ of the 3rd larval instars, in 5,7 and 9 days respectively (Fig. 5) on the one hand. Likewise, $8.78 \times 10^{35}, 4.08 \times 10^{29}$ and $2.19 \times 10^{23}$ conidia. $\mathrm{mL}^{-1}$ of $\mathrm{Bb} 115$ isolate i.e. $8.78 \times 10^{32}, 4.08 \times 10^{26}$ and $2.19 \times 10^{20}$ conidia per insect were needed to kill $50 \%$ of 3rd larval instars, in 5, 7 and 9 days (Fig. 6) on the other hand. The isolate $\mathrm{Bb} 11$ gave the highest $B$ value $(0.087)$ and therefore the lowest LC50 values. The width of the confidence intervals was narrower for Bb11 compared to those of the other isolates. Thus, $1.73 \mathrm{x}$ $10^{19}, 4.91 \times 10^{15}$ and $1.75 \times 10^{13}$ conidia. $\mathrm{mL}^{-1}$ of $\mathrm{Bb} 11$ i.e. $1.73 \times 10^{16}, 4.91 \times 10^{12}$ and $1.75 \times 10^{10}$ conidia per insect were needed to kill $50 \% 3^{\text {rd }}$ larval instars of $H$. derogata in 5,7 and 9 days respectively (Fig. 7 ).

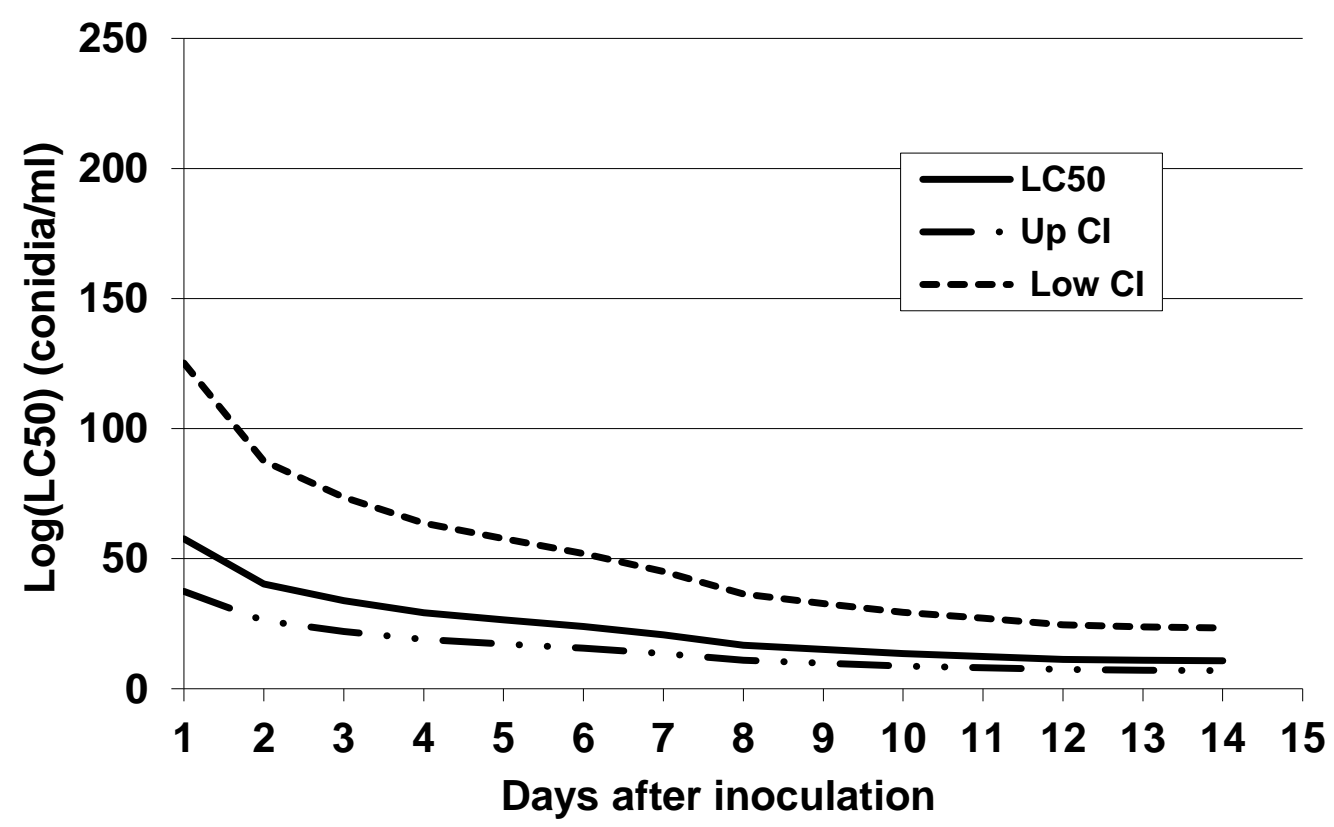

Fig. 5 LC50 values after treatment of the third stage of Haritalodes (=Syllepte) derogata to various doses of Bb3. 


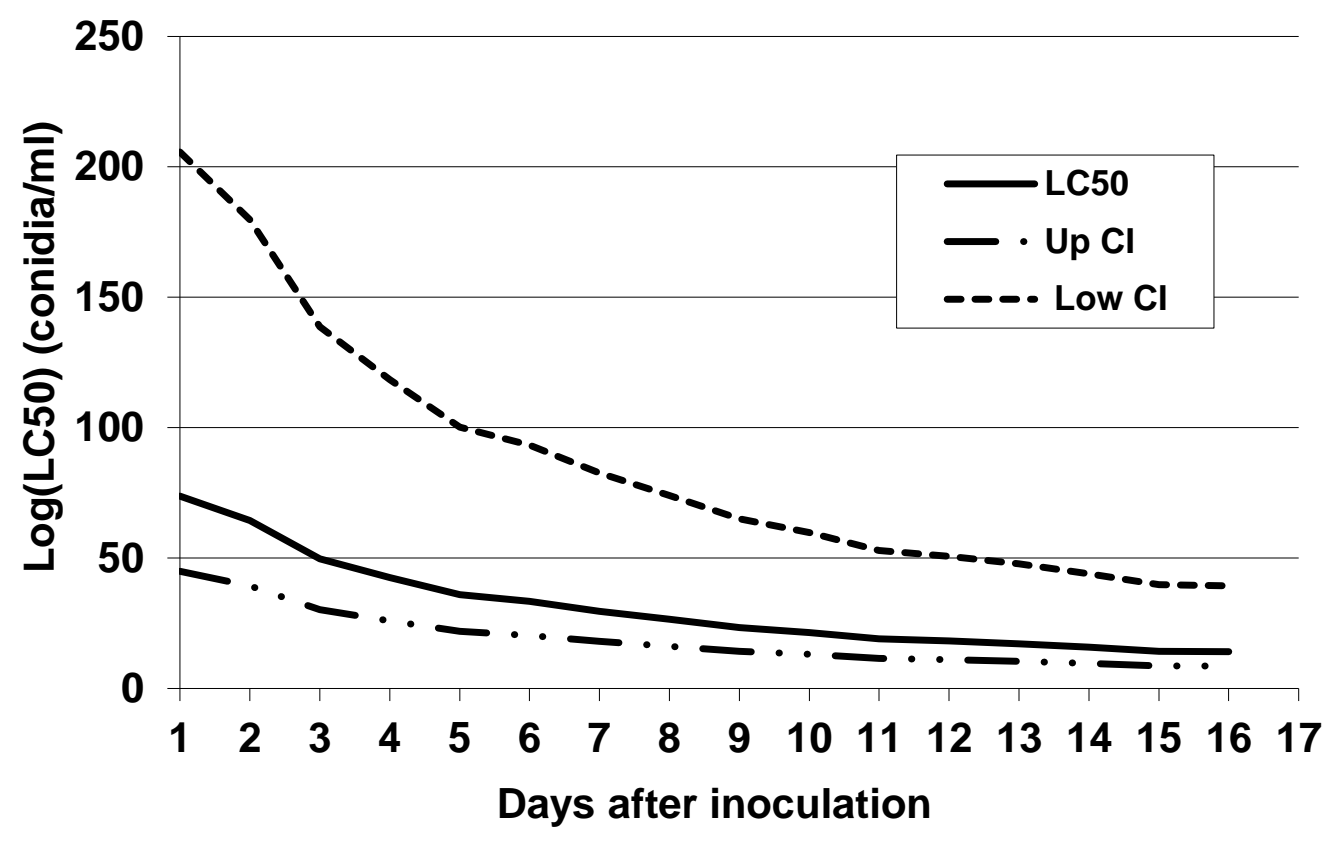

Fig. 6 LC50 values after treatment of the third stage of Haritalodes (=Syllepte) derogata to various doses of Bb115.

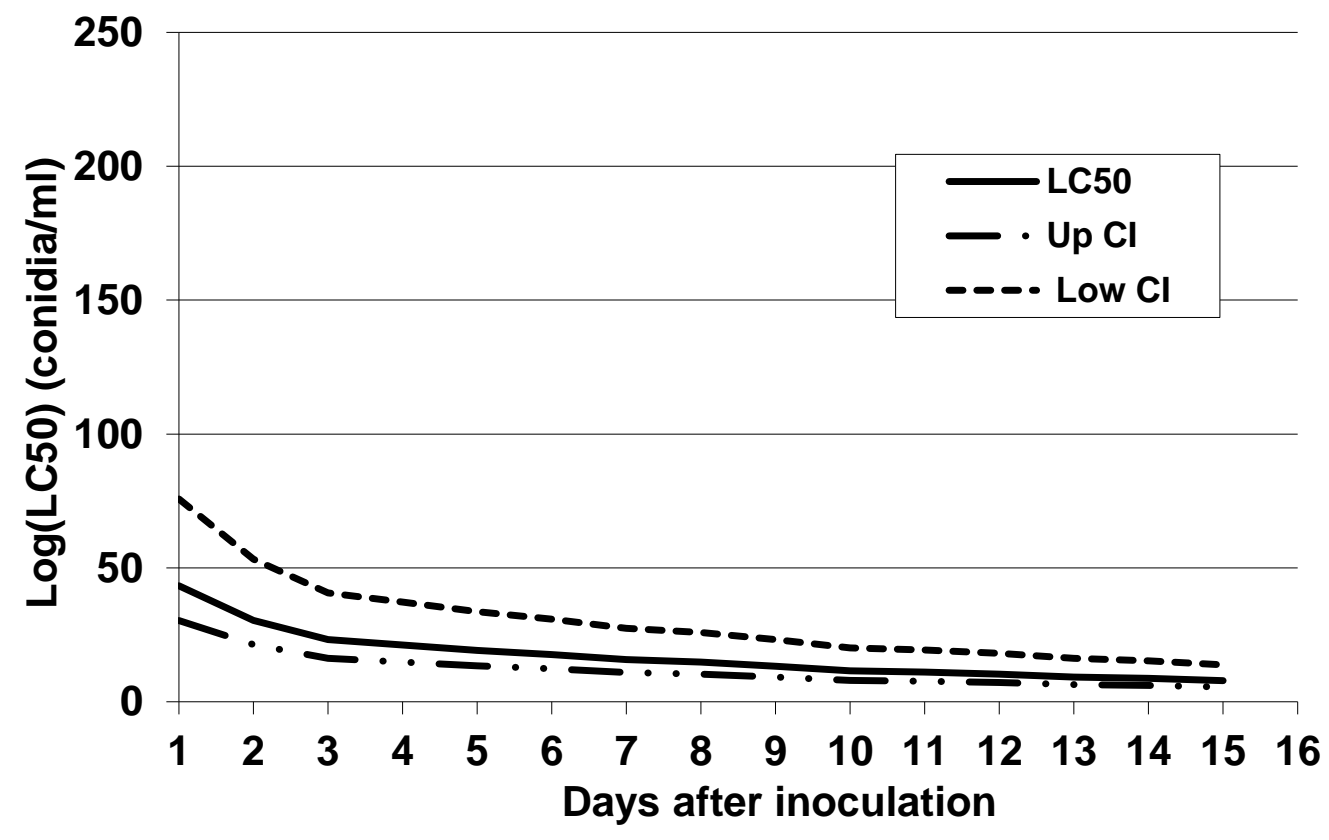

Fig. 7 LC50 values after treatment of the third stage of Haritalodes (=Syllepte) derogata to various doses of Bb11. 


\section{DISCUSSION}

Mortality and sporulation of larvae: Results of this study indicated that the third larval stages were susceptible to infection of $B$. bassiana isolates tested. Mortality rate is depending on the type of isolate. Indeed, the highest mortality rate was obtained with the isolate Bb2. Such difference could be explained by its great capacity to produce enzymes and more toxic metabolites than others (Ferron, 1981). Valda et al. (2003) obtained similar results with mortality that ranging between 70 and $96 \%$ in Plutella xylostella treated with different $B$. bassiana isolates. In addition to $\mathrm{Bb2}$, other isolates namely $\mathrm{Bb} 116, \mathrm{Bb} 11, \mathrm{Bb} 3$ and $\mathrm{Bb} 5$ induced statistically similar mortality rates and higher virulence on the tested insect host. The difference in virulence between the various isolates may be related to their origin $f$ and in some cases to the first species from which the isolate was cultured (same insect family or order). Our findings were in concordance with previous studies done by McCoy et al. (1988) and Goettel, (1992), who stated that an isolate was generally more virulent to the family and host area from which it has been isolated. Likewise, sporulation rate varied from isolate to isolate and the highest on dead larvae resulted from the use of Bb116. In this perspective, some isolates induced a germination of the fungus on the cuticle of incubated cadavers. This variability, which due to their difference of pathogenicity results from their virulence on the larvae of $H$. derogata. Similar results have been reported by Douro Kpindou et al. (2012) and Toffa-Mehinto (2014) on Helicoverpa armigera (Hübner) (Lepidoptera: Noctuidae) and Maruca vitrata Fabricius (Lepidoptera; Crambidae), respectively. In addition, dead larvae from some isolates such as $\mathrm{Bb} 338, \mathrm{Bb} 353, \mathrm{Bb} 69$ and $\mathrm{Bb} 84$ did not sporulate. Moreover, other isolates namely $\mathrm{Bb} 2, \mathrm{Bb} 5$ and $\mathrm{Bb} 71$ had a low sporulation rate less than $10 \%$ but a higher mortality as mentioned previously. The susceptibility of the insect would therefore be influenced by their innate virulence. This observation was in agreement with the views of Soetopo (2004) who reported that the innate virulence of the isolate could induce high mortality with low sporulation rate. However, the choice of isolates depends primarily on their pathogenicity and the susceptibility of the host insect (Prior, 1990; Tanada and Kaya, 1993;). In the present case, when identifying the most virulent isolates after screening, sporulation and mortality could be determining parameters in the choice of the most virulent isolates as suggested by Jamal (2008) and Groden \& Lockwood (1991). Thus, five isolates are found to be promising due to their ability to cause a high rate of mortality and to induce a relatively high sporulation rate. These included the isolates $\mathrm{Bb} 116$, $\mathrm{Bb} 3, \mathrm{Bb} 11, \mathrm{Bb} 6$ and $\mathrm{Bb} 115$.

Effect of concentrations on larvae and adults' emergence: The most promising isolates $\mathrm{Bb} 3, \mathrm{Bb} 11$ and $\mathrm{Bb} 115$ used for assessing the effect of different concentrations were chosen taking into account their origin from Benin (case of $\mathrm{Bb} 3$ and $\mathrm{Bb} 11$ ) and their effectiveness on other Lepidopteran pests such as $H$. armigera (Douro Kpindou et al., 2012) and M. vitrata (Toffa Mehinto, 2014) for the cases of Bb11 and Bb115, respectively. The mortality rates increased with the concentration within each isolate. This suggests that the mortality rate depends on the quantity of conidia received. In some isolates, several concentrations induced similar mortality rate. For example, in isolate Bb11, no significant difference was obtained for concentrations $10^{5}, 10^{6}$ and $10^{7}$ conidia per $\mathrm{mL}$, and the highest mortality was recorded at $10^{8}$ and $10^{9}$ conidia per $\mathrm{mL}$ using the third larval instars of $H$. derogata. The highest mortality rate was observed in $\mathrm{Bb} 11$ (76.66 \pm $1.66 \%$ ) with the lowest emergence rate (33.33 \pm $17.63 \%$ ) of adults suggests that $\mathrm{Bb} 11$ was better compared to the other isolates $\mathrm{Bb} 3$ and $\mathrm{Bb} 115$.

Lethal Concentration (LC50) of B. bassiana on third $H$. derogata larval stage: Models that combine time and dose effects seem to be more appropriate for assessing the effectiveness of a pathogen or pesticide on target insect species (Robertson et al., 1992). Of these Cox regression model was more flexible in the analysis of bioassays on biopesticides than other models such as Probit and Logit analyses (Douro Kpindou et al., 2012). Probit analysis and Logit regression analysis have found wide use in modelling the probability of a dose response (Finney, 1971; Robertson et al., 1992). Cox regression models based on the time-dose relationship of $B$. bassiana isolates for the survival of infected larvae of $H$. derogata fitted well in the current study. All B values given by Cox regression model were all significant $(P<0.05)$. In consequent, our data showed a significant effect / dose response. Similarly, the LC50 curves had good trend and their confidence intervals were relatively narrower. Our results were comparable to those obtained by Douro Kpindou et al. (2012) when using virulent isolates of fungi $M$. anisopliae and $B$. bassiana on $\mathrm{H}$. armigera. Based on LC50, isolate $\mathrm{Bb} 11$ was found to be more virulent followed by Bb3 and Bb115. 


\section{CONCLUSION AND APPLICATION OF RESULTS}

Among $B$. bassiana isolates used for the screening, some showed their potential for the control of $H$. derogata through their virulence. These isolates delayed the growth of treated caterpillars and finally killed them.

\section{ACKNOWLEDGMENTS}

We thank the national fund for scientific research and technological innovation from Benin (FNRSIT) for financial support of this study. We also thank the other members of the project "Lutte biologique contre les ravageurs du cotonnier (LuBiRaC) au Bénin" [Biological

\section{REFERENCES}

Afouda R, Ahlonsou R, Amoussouga TB, Djihoun M, 2013. La filière coton tisse sa toile au Bénin, AgriProfocus [The cotton sector weaves its web in Benin, AgriProfocus].

Althouse CM, Petersen BE, McEwen LC, 1997. Effects of young American kestrels (Falco sparvericus) exposed to Beauveria bassiana bioinsecticide. Bull. Environ. Contam. Toxicol, 59: 507-12.

Bateman RP, Carey M, Moore D, Prior C, 1994. The enhanced infectivity of Metarhizium flavoviride in oil formulations at low humidities. Ann. Appl. Biol., 122:145-52.

Brevault T, Renou A, Goebel R, Clouvel P, 2017. Repenser la gestion des ravageurs du cotonnier. Les Zones Cotonnières Africaines, Dynamiques et Durabilité [Rethinking the management of cotton pests. African Cotton Zones, Dynamics and Sustainability], 399-412.

CRA-CF, 2018. Rapport de la campagne cotonnière de 2017-2018 [Cotton campaign report for 20172018]

Dannon HF, Dannon AE, Douro-Kpindou OK, Zinsou AV, Houndeté AT, Toffa-Mehinto J, Elégbédé IATM, Olou BD and TAMÒ M, 2020. Toward the efficient use of Beauveria bassiana in integrated cotton insect pest management. Journal of Cotton Research 3(1): 1-21. https://doi.org/10.1186/s42397-020-00061-5

Djihinto AC, Katary A, Prudent P, Vassal JM, Vaissayre M, 2009. Variation in Resistance to Pyrethroids in Helicoverpa armigera from Benin Republic, West Africa. Journal of Economic Entomology, 102(5): 1928-1934. https://doi.org/10.1603/029.102.0525

Djihinto CO, Affokpon A, Dannon E, Aboua C, 2016. Réduction de doses de cyperméthrinetriazophos et lutte raisonnée en culture
Three of virulent isolates were more promising (Bb11, $\mathrm{Bb} 3$ and $\mathrm{Bb} 115)$ and could be included in a new strategy of cotton integrated pest management.

control of cotton pests (LuBiRaC) in Benin]. We thank Robert AHOMAGNON for his technical assistance at the International Institute of Tropical Agriculture (IITABenin).

cotonnière au Bénin [Reduction of doses of cypermethrin-triazophos and reasoned control in cotton cultivation in Benin]. Journal of Applied Biosciences, $\quad 98$ : 92619269.https://doi.org/10.4314/jab.v98i1.3

Douro Kpindou O, Djegui DA, Glitho IA, Tamò M, 2012. Sensitivity of Helicoverpa armigera (Hübner) (Lepidoptera: Noctuidea) to the entomopathogenic fungi, Metarhizium anisopliae and Beauveria bassiana in laboratory. ARPN Journal of Agricultural and Biological Science, 7: 10071015.https://hdl.handle.net/10568/80862

Douro Kpindou O, Djegui DA, Glitho IA, Tamò M, 2012. Réponse des stades larvaires de Helicoverpa armigera (Hübner) (Lepidoptera: Noctuidae) à l'application de champignons entomopathogènes Metarhizium anisopliae et Beauveria bassiana [Response of the larval stages of Helicoverpa armigera (Hübner) (Lepidoptera: Noctuidae) by the using of entomopathogenic fungi Metarhizium anisopliae and Beauveria bassiana]. Biotechnology, Agronomy and Society and Environment, $16(3)$ : 283-293. https://hdl.handle.net/10568/80842

Douro Kpindou OK, Paraïso A, Djegui DA, Glitho IA, Maffon S and Tamo M, 2013. Comparative study of the efficacy of Entomopathogenic fungi, chemicals and botanical pesticides in the management of cotton pests and their natural enemies in Benin. International Journal of Science and Advanced Technology,3(1):2133.

https://doi.org/https://www.researchgate.net/pu blication/236159740 
Fari M, Wraight SP, 2001. Biological control of Bemisia with fungi. Crop Protect, 20: 767-778.

Ferron $P, 1981$. Pest control by the fungi Beauveria and Metarhizium. Microbial control of pests and plant diseases, 1970-1980.

Finney DJ, 1971. Probit analysis. 3rd ed. Cambridge: Cambridge University Press.

Gahramanova G, Mamay M, Mammadov Z, 2020. Biological characteristics and efficacy of Bacillus thuringiensis var. thuringiensis against the cotton leaf roller, Syllepta derogata (Fabricius, 1775) (Lepidoptera : Crambidae). Egyptian Journal of Biological Pest Control, 30(85): 1-7. https://doi.org/https://doi.org/10.1186/s41938020-00289-y

Ganda H, Togbé EC, Houndété TA, Zannou Boukari ET, Gogan M, Dagbénonbakin GD and Kossou DK, 2018. Effectiveness of neem seed oil (Azadirachta indica A. Juss: Meliaceae) on Syllepte derogata Fabricius, Lepidoptera: Pyralidae. Journal of Applied Biosciences, 129:13029-13038.

https://doi.org/http://dx.doi.org/10.4314/jab.v12 $9 i 1.6$

Goettel MS, 1992. Biological control of locusts and grasshoppers. Wallingford, UK: CAB. International, 122-130.

Groden E and Lockwood JL, 1991. Effects of soil fungistasis on Beauveria bassiana and its relationship to disease incidence in the Colorado potato beetle, Leptinotarsa decemlineata, in Michigan and Rhode Island soils. Journal of Invertebrate Pathology, 57(1): 7-16. https://doi.org/10.1016/00222011(91)90036-P

Héma O, Somé Hugues N, Traoré O, Greenplate J, Abdennadher M, 2009. Efficacy of transgenic cotton plant containing the Cry1 Ac and Cry2Ab genes of Bacillus thuringiensis against Helicoverpa armigera and Syllepte derogata in cotton cultivation in Burkina Faso. Crop Protection, $28: 205-214$. https://doi.org/10.1016/j.cropro.2008.09.014

Jamal Z, 2008. Application de Beauveria bassiana contre la punaise terne Lygus lineolaris (palisot de beauvois) (hémiptères: miridés) dans les vignobles [Application of Beauveria bassiana against Lygus lineolaris (palisot de beauvois) (hemiptera: miridae) in vineyards] [Thèse de doctorat]. Montréal: Université du Québec.
Lambert N, 2010. Lutte biologique aux ravageurs: applicabilité au Québec [mémoire de maîtrise en environnement (M.Env.)]. Québec: Université de Sherbrooke.

Lawani RAN, Kelome NC, Agassounon D, 2017. Effets des pratiques agricoles sur la pollution des eaux de surface en République du Bénin [Effects of agricultural practices on the pollution of surface water in Benin Republic]. Larhyss Journal; 30:173-190.

Mascarin MG and Jaronski TS, 2016. The production and uses of Beauveria bassiana as a microbial insecticide. World J. Microbiol Biotechnol, 32(177): 1-26.

McCoy CW, Samson RA, Boucias DG, 1988. Entomogenous fungi. In: CM Ignoffo and NB Mandava (Editors), Handb. Nat. Pestic., Volume V: Microbial Insecticides, Part A, Entomogenous Protozoa and Fungi. CRC Press, Boca Raton, FL, pp. 151- 236.

OECD, 2010. Sediment-water chironomid life-cycle toxicity test using spiked water or spiked sediment. OECD guidelines for the testing of chemicals. 233, 1-30.

Peveling R and Demba SA, 1997. Virulence of the entomopathogenic fungus Metarhizium flavoviride gams and rozsypal and toxicity of diflubenzuron, fenitrothion- esfenvalerate and profenofos-cypermethrin to nontarget arthropods in Mauritania. Arch. Environ. Contam. Toxicol., 32: 69-79.

Prior C, 1990. The biological basis for regulating the release of micro-organism, with particular reference to the use of fungi for pest control. Asp. Appl. Biol., 24: 231-238.

Robertson JL and Preisler HK, 1992. Pesticide bioassay with arthropods. London: CRC Press.

Sabbahi $\mathrm{R}, 2008$. Utilisation $d u$ champignon entomopathogène Beauveria bassiana dans une stratégie de gestion phytosanitaire des principaux insectes ravageurs en fraiseraies (Thèse de Philosophiae Doctor en Biologie) [Use of the entomopathogenic fungus Beauveria bassiana in a strategy of phytosanitary management of the main insect pests in strawberry plantations (Doctoral dissertation in Biology)]. Université du Québec : Institut national de la recherche scientifique, INRS-Institut Armand-Frappier.

Sahayaraj K, Namachivayam SKR, 2011. Field evaluation of three entomopathogenic fungi on 
groundnut pest field evaluation of three entomopathogenic fungi on groundnut pests. Tropicultura, $29(3): 143-147$ https://doi.org/https://www.researchgate.net/pu blication/265729758

Silvie P, 1993. Les parasitoïdes de Syllepte derogata (Fabricius, 1775) (Lepidoptera, Crambidae) au Togo. J. Afr. Zool., $107:$ 363-372.

Silvie PJ, Renou A, Vodounnon S, Bonni G, Adegnika MO, Héma $O$, Prudent $P$, Sorèze $J, \ldots$ Brévault $\mathrm{T}$, 2013. Threshold-based interventions for cotton pest control in West Africa : What's up 10 years later? Crop Protection, 43: 57-165. https://doi.org/10.1016/j.cropro.2012.09.006

Soetopo D, 2004. Efficacy of selected Beauveria bassiana (Bals.) Vuill. isolates in combination with a resistant cotton variety (PSB-Ct 9) against the cotton bollworm, Helicoverpa armigera (Hübner) (Lepidoptera: Noctuidae) PhD diss., University of The Philippines Los Banos.

Steel RGD, Torrie JH and Dickey DA, 1997. Principles and procedures of statistics: a biological approach. McGraw-Hill, $666 \mathrm{pp}$.

Streito JC, Nibouche S, 1997. First observations on the parasitoids associated with Lepidopterous pests of cotton in Burkina-Faso. Entomophaga, 42(4) : 543-557.

Tanada Y, Kaya H 1993. Insect pathology. Academic Press, San Diego, CA. 666 pp.

Toffa Mehinto J, Atachi P, Douro-Kpindou OK, Tamò M, 2014. Pathogenecity of entomopathogenic fungi Metarhizium anisopliae and Beauveria bassiana on larvae of the legume pod borer Maruca vitrata (Lepidoptera: Crambidae). ARPN Journal of Agricultural and Biological Science. 9(2): 55-64.

Tonavoh F, 2019. Le Bénin premier producteur du coton en Afrique de l'Ouest. Economie, news.orificegroup.net [Benin, the leading producer of cotton in West Africa. Economy, news.orificegroup.net].

Valda CA, Silva RB, Edmilson JM, Jorge BT, 2003. Susceptibility of Plutella xylostella (L.) (Lepidoptera: Plutellidae) to fungus Beauveria bassiana (Bals.) Vuill and Metarhizium anisopliae (Metsch.) Sorok. Neotrop. Entomol. 32 (4): 653-658.

Westerberg V, 2017. The Economics of conventional and organic cotton production. A case study from the municipality of Banikoara, Benin.
Report for the Economics of Land Degradation Initiative, 36p.

Zimmermann G, 2007. Review on safety of the entomopathogenic fungi Beauveria bassiana and Beauveria brongniartii. Biocontrol Science and Technology, 17(6): 553596.https://doi.org/10.1080/095831507013090 $\underline{06}$ 